\title{
Investigating Effects of Self-Efficacy and Infrastructure on Teachers' ICT Use, an Extension of UTAUT
}

\author{
Arnab Kundu, Bankura University, West Bengal, India \\ (iD) https://orcid.org/0000-0002-7169-7189 \\ Tripti Bej, Srima Balika Vidyalaya, West Bengal, India \\ (iD) https://orcid.org/0000-0002-3662-5788 \\ Kedar Nath Dey, SDDK Mahavidyalaya, West Bengal, India
}

\begin{abstract}
Information and communication technology (ICT), an effective teaching tool for 21 st-century classrooms, needs few factors for its effectual use as evidenced in the Unified Theory of Acceptance and Use of Technology (UTAUT) model. The purpose of this empirical investigation was to investigate the effect of two such significant factors teachers' self-efficacy and perceived infrastructure, on their ease of ICT use. The study employed a descriptive survey method within an ex-post-facto research design taking 400 teachers as samples from 100 purposively selected Indian secondary schools. Data were analyzed descriptively and inferentially. Regression analyses were conducted to find out the effects of two independent variables on the dependent variable. Results revealed that perception of self-efficacy and infrastructure were significant predictors of the teachers' ease of ICT use. The two independent variables were found to have a high collective prediction on the teachers' ICT use behavior and for every 1 standard unit simultaneous increase self-efficacy and perceived infrastructure, the ease of ICT use will increase by 0.94 standard unit. Perceived infrastructure was found to have a stronger individual effect on the ease of use than self-efficacy. The findings support the UTAUT model and advocate its further extension towards UTAUT+ adding these two new factors to the existing model.
\end{abstract}

\section{KEYWORDS}

ICT, ICT Infrastructure, School Teacher, Self-Efficacy, UTAUT

\section{INTRODUCTION}

The great Indian saint Swami Vivekananda proposed that if the poor cannot come to education, education must reach them at the plow, in the factory, and everywhere (The Complete Works of Swami Vivekananda, 2012). This vision of Swamiji is highlighted in today's ICT-enabled teachinglearning potent to overcome many educational limitations in respect of quality and quantity. Passing through a series of hard processes finally in the 21 st century has been witnessing a revolution in ICT use influencing every domain of human activity including education. The integration of ICTs in teaching-learning is essential as it creates more chances for teachers and learners to work better in an information age (Nkula \& Krauss, 2014). Kundu \& Dey (2018a) said technology has been 
proved to be a huge revolution in the field of education, be it the newly joined school kids or the great scholars and researchers, technology has tamed them all. Several researchers have found ICTs have the potential to innovate, accelerate, enrich, and deepen skills, to motivate and engage students, to help relate school experience to work practices, create economic viability for tomorrow's workers, as well as strengthening teaching, helping schools change with greater learning opportunities for the learners (Kundu \& Bej, 2020; Minty \& Parther, 2014; Ndlovu \& Lawrence, 2012; Mdlongwa, 2012; Chigona, 2015; Minty \& Pather, 2014; Bakar, Ayub, Luan, \& Tarmizi, 2010; Yee, Luan, Ayub, \& Mahmud, 2009; Yusuf, 2005). It can transform and create innovative pedagogical approaches in the instructional process (Chen, 2007; Luan, Atan, \& Sabudin, 2010). Studies assessed that computer has increased students' interest in education which impact on their motivation, enrolment, engagement, achievement, attendance, retention, level of motivation and collaboration (Kundu, Bej, \& Rice, 2020; Kundu, Bej, \& Dey, 2021; Zang \& Aikman 2007; Kubiatko, 2013; Zhao \& Cziko, 2001). Chou (2003) sounded more rhetorical that ICT is a tool to revolutionize education, improve learning, empower learners, produce richer curricula, enhance pedagogies, and will lead to more effective organizational structures in schools producing stronger links between schools and society. Unwin (2009) specifically claimed that ICT can be a catalyst by providing tools that tutors use to improve teaching and by giving learners access to electronic media that make concepts clearer and more accessible. UNESCO (2003) also recommended the member nations for ICT to achieve the goal of 'Education for All' to the best educational facilities necessary to prepare young people to play full roles in modern society and to contribute to a knowledge nation. The educational systems across the globe are under increasing pressure to leverage the full potential of ICTs in teaching-learning by enhancing its ease of use (Minty \& Pather, 2014). But its implementation was delayed if not ignored in several nations and the pandemic outbreak of COVID-19 that has opened up their eyes to implement ICT policies in a war-like manner understanding and mastering the unique capability of ICTs in providing a dynamic and proactive teaching-learning environment keeping social distancing (Kundu \& Bej, 2020a).

\section{Difficulties of ICT Integration in Pedagogy}

ICT integration in pedagogy is no doubt a difficult task that needs few special conditions and skills for both humans and non-human agents that has been convincingly shown in the Technology Acceptance Model (TAM), developed by Davis (1989), and in the Technological Pedagogical Content Knowledge (TPACK) Framework developed by Mishra \& Koehler (2006). Both the models show the ease of ICT use depends on the effective supports from several internal and external factors. ICT use and ICT integration are two different concepts as Wilson-Strydom \& Thompson (2005) viewed them and said the idea of ICT integration in curriculum delivery a deeper concept than simple computer literacy or technical knowledge of computers which is meant to be cross-curricular rather than become a separate course or topic in itself. They argued that the acquisition of technical skills and learning about computers is implementation without integration whereas learning through or using a computer is referred to as implementation with integration. Harding (2012) said teacher is one of the most important factors because they are the ones who blend all the educational components to deliver environments for teaching and learning. In this context, Nkula \& Krauss (2014) found ICT integration neither refer to simply placing computers in the classroom nor using technology to sustain traditional teaching methods, rather integration refers to the use of technology to promote teaching-learning, that is, where students use ICTs in acquiring new knowledge and skills making teaching itself an intricate and impressive function. This claim finds evidence in the observation of Aldunate \& Mehlenbacher (2010) who said research conducted in countries with different cultures reported that although there was an increase in the availability of ICT tools in schools there is an indication that teachers were not using ICT as expected. Balanskat, Blamire, \& Kefala (2006) reported that teachers appreciate the role of ICT in classrooms but they are continuously found obstacles in using these technologies in the teaching-learning process. In this context, Kundu (2018c) said teachers' roles and willingness to accept educational technology is very vital for its effective integration in pedagogy. Thus, more 
research and comprehensive preparation is needed to leverage the full potential of ICTs in pedagogy considering more internal and external factors. This study is an investigation into two such factors, self-efficacy and ICT infrastructure to infer on their potential in users' ability.

\section{Self-Efficacy, an Internal Factor for ICT Integration}

Avant-guard spokesman of self-efficacy concept, Bandura (1997) said self-efficacy is not a global trait rather it is both domain and context specific, therefore, he stressed that because of the rapid development of technological tools, the pedagogical use of technology may require special types of teachers' self-efficacy. He argued in Benight \& Bandura (2004) that if teachers have high self-efficacy regarding their ability to use technology, they will be more willing to adopt new technologies in their classroom practices. Recent researches already mentioned regarding self-efficacy and the use of ICT in teaching corroborates Bandura's assumptions and underscores the notion that increased levels of computer self-efficacy can lead to higher levels of confidence in being an efficient teacher with ICT (Fanni et al., 2013). A lot of studies found teachers' beliefs, attitudes, confidence, motivations, readiness, and self-efficacy are fundamentals for effective integration of ICTs in pedagogy (Erdogan, 2011; Harding, 2012; Badia et al., 2013; Oye et al., 2014; Tschannen-Moran \& Hoy, 2001). A lot of other studies specifically found that self-efficacy is essential for successful integration of technology in education (e.g., Kundu, 2020; Pumptow \& Brahm, 2020; Hatlevik \& Hatlevik, 2018; Hong, Hwang, Tai, \& Lin, 2017; Vayre \& Vonthron, 2016; Oye et al., 2014; Al-Ruz \& Khasawneh, 2011; Chen, 2008; Lin, Wang \& Lin, 2012; Sang et al., 2011). Hatlevik (2017) and Badia et al. (2013) found many teachers were aware of the technology that was available to them for instructional purposes, yet for one or more reasons, they were not found capitalizing on the unique opportunities to integrate such resources into their classroom practices. Sun \& Chen (2016) said that teachers who feel uncomfortable using technology are unlikely to incorporate it and has attributed this underutilized technology infrastructure to teachers' lack of self-efficacy. Teo (2014) and Hatlevik (2017) demonstrated a positive relationship between self-efficacy about using digital tools and the use of ICT for teaching purposes. But studies like Pumptow \& Brahm (2020), Hatlevik \& Hatlevik (2018), or Ertmer \& Ottenbreit-Leftwich (2010) found several other internal factors make this integration successful for the teachers like technological knowledge, pedagogical knowledge, content knowledge, that jointly composed teachers' ICT selfefficacy belief. These are all teacher related human factors affecting ICT use.

\section{Infrastructure, an External Factor for ICT Integration}

The Technology Acceptance Model also put a place of external factors affecting ICT integration. Later, a variety of external factors have been identified influencing ICT integration in school pedagogy including technology availability, accessibility of ICT equipment, time to plan for instruction, technical and administrative support, school curriculum, school climate and culture, faculty teaching load, and management routine, and pressure to prepare students for national entrance exams (Al-Ruz and Khasawneh 2011; Lin, Wang and Lin 2012; Tezci, 2011; Kundu \& Dey, 2018b). Krysa (1998) said these external factors are commonly called ICT infrastructure. Vanderlinde \& van Braak (2010) defines ICT infrastructure as the perceived availability and suitability of the ICT tools such as hardware, software, and peripheral equipment provided in the school that facilities and enables schools in the direction of supporting continuous transformation and development of various learning approaches. Shiue (2007) found outmoded hardware and software limit the use of computers in instruction and the teacher was not able to integrate technology into instruction due to the old and outdated hardware. Cowie \& Jones (2005) said with the ICT infrastructure provides the teachers access to the school network and the internet and laptop accessories like printer, digital camera, data projector, large TV screen, scanner, and video camera. Moses, Bakar, Mahmud \& Wong (2016) said the educators have more prospects to utilize instructional technology when the ICT infrastructures are provided in a good manner. Pelgrum \& Law (2003) said effective ICT integration has a dependency on the perceptions and vision of school leaders. School culture is also considered as an important element 
in the implementation of ICTs (Albirini, 2006) that plays a crucial role in influencing how teachers relate their beliefs to ICT use having a mediating role that influences teachers' actions, beliefs, and attitudes (Chai, Hong, \& Teo, 2009). Cultural differences have also been identified in the study of Kundu (2018c) where Indian teachers found perceiving themselves more of an authority role compared to Western teachers that negatively impact on the teachers' use of educational technology. Kundu, Bej, \& Dey (2020), Vanderlinde \& van Braak (2010), and Moses, Bakar, Mahmud \& Wong (2016) found good ICT infrastructure yields good integration in pedagogy. Frost \& Sullivan (2006) have characterized technical support as the access, operation, and troubleshooting of hardware, software, and network resources. Technology support has an encouraging impact on educators' uses of ICT (Moses et al., 2008) and their integration of ICT into the teaching-learning practices as well (Dexter, Seashore, \& Anderson, 2003). Kundu, Bej, \& Dey (2020) found a close positive correlation between self-efficacy and ICT infrastructure that sounds like a fine recipe for academic success when selfefficacy could put an escalating effect on the teachers' productive and easeful use of technology in pedagogy. For these reasons, it is essential to provide guidance, support, and services as parts of the technology applications (Haslaman, Mumcu, \& Usluel, 2008; Moses, Bakar, Mahmud \& Wong, 2016). Theses and several other studies (e. g. Cowie \& Jones, 2005; Shiue, 2007) have shown clearly that ICT infrastructure can be one of the factors that influence the teachers' ability of technology integration in pedagogy. It is a holistic concept and can be divided into two broad clusters- technical Support and management support. Technical support is specialized skill personnel who can support and assist the educators in implementing technology into instruction (Resta, 2002). Administrative support, as Baylor \& Ritchie (2002) said, in the presence of encouraging ICT using role models, such as the principal. Afshari, Bakar, Luan, Samah, \& Fooi (2008) said these principals need to become proficient in the use of ICT to provide technology leadership in administrative, instructional, and learning functions what Baylor \& Ritchie (2002) said they would need to figuratively 'roll up their sleeves and join in instead of sitting by the side' (p. 412). The encouragement and support by the principals motivate the teachers to incorporate ICT in their teaching (Ali, Nor, Hamzah, \& Alwi, 2009). Besides school management has also a big role in flourishing befitting ICT culture in a school (Ali et al., 2009; Samuel \& Bakar, 2006; Moses, Bakar, Mahmud \& Wong, 2016; Kundu, Bej, \& Dey, 2020).

\section{Literature Gap}

The above literature review reveals that ICT use in school pedagogy is an effective step towards promoting and enhancing the knowledge, understanding, and experience of the teachers and students. Its vitality becomes more dominant in the post-COVID-19 world order of new thought and living (Kundu \& Bej, 2021). But becomes also evident that ICT integration in teaching is a complex task that needs several factors to perform consensus close communion. Several past studies focused on different factors but no study has yet been concentrated on the combined effects of self-efficacy and ICT infrastructure on the teachers' ability perception of ICT use. The current study targeted this research gap.

\section{Theoretical Frameworks}

Knowledge needs to be referential, new knowledge must have a claim in the previous knowledge pool, and a theoretical framework helps in establishing this nexus. In the current study, considering the research gap, the authors have adopted the Unified Theory of Acceptance and Use of Technology (UTAUT) model developed by Venkatesh, Morris, Davis \& Davis (2003) several years ago out of the Technology Acceptance Model (TAM). The UTAUT is an extension of TAM and developed to explain the reason for ICT skill acquisition is comprehensive of all human existence having four key constructs (i.e., performance expectancy, effort expectancy, social influence, and facilitating conditions) that influence behavioral ability to use technology. This model puts a lot of space for further excavation, research, and accumulation to test and add more factors facilitating the ease of ICT use (Fathema, Shannon, \& Ross, 2015). The current study is a probe into this direction and an 


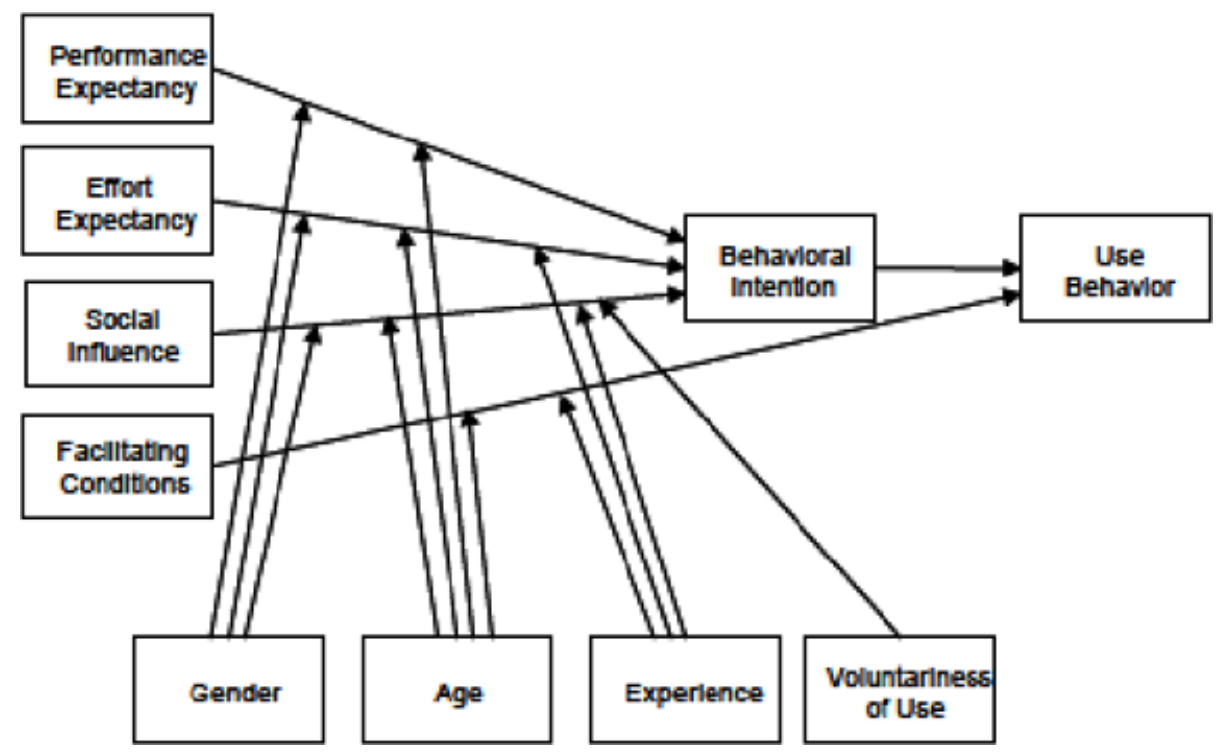

investigation on assuming two more factors affecting users' technology using ease. The assumed extension of UTAUT + has been presented in Fig. 1. The dotted lines show the assumed effects of the two proposed factors which are to be empirically investigated here.

\section{Research Aim}

Based on the above theoretical consideration, the present study aimed at answering the following research questions (RQ):

RQ1: How does teachers' self-efficacy affect their ease of ICT use?

RQ2: How does teachers' perceived infrastructure affect the ease of ICT use?

RQ3: How do self-efficacy and infrastructure together affect teachers' ease of ICT use?

Hypothesis Formulation

H01: There is no relationship between teachers' self-efficacy and ease of ICT use.

H02: There is no relationship between perceived ICT infrastructure and ICT use.

H03: Teachers' self-efficacy and perceived infrastructure do not affect their ease of ICT use.

The proposed research model adopts in this study seeks an extension of the UTAUT having selfefficacy and infrastructure as the assumed factors affecting users' behavioral ability of ICT use. The dotted line shows the proposed interrelationships among three variables which is the main objective of this investigation and accordingly the following structural equation modeling was conceived (see Fig. 2) to empirically assess the authenticity of the proposed UTAUT + .

\section{Method}

This study followed the descriptive survey method within ex-post-facto research design taking teacher's self-efficacy and perceived ICT infrastructure as the predictive variables and ability of ICT use as the criterion variable. The research approach followed was quantitative and correlational which Creswell 
Table 1: Demographic details of the participants

\begin{tabular}{|l|l|l|}
\hline Demographic Variable & Frequency (N=300) & Percentage (\%) \\
\hline District & \multicolumn{2}{|l|}{} \\
\hline Bankura (BNK) & 60 & 20 \\
\hline Purulia (P) & 60 & 20 \\
\hline Paschim Medinipur (PM) & 60 & 20 \\
\hline Paschim Burdwan (PB) & 60 & 20 \\
Birbhum (BIR) & 60 & 20 \\
\hline Gender & \multicolumn{2}{|l|}{} \\
\hline Male (M) & 200 & 66.67 \\
Female (F) & 100 & 33.33 \\
\hline Age Groups (years) & \multicolumn{2}{|l|}{} \\
\hline 20-30 (Y1) & 101 & 33.67 \\
31-40 (Y2) & 92 & 30.67 \\
41-50 (Y3) & 44 & 14.66 \\
More than 51 (Y4) & 63 & 21 \\
\hline Management types & \multicolumn{2}{|l|}{} \\
\hline Government (G) & 215 & 71.67 \\
Private (P) & 85 & 28.33 \\
\hline School Location & \multicolumn{2}{|l}{} \\
Urban (U) & 142 & 47.33 \\
Rural (R) & 158 & 52.67 \\
\hline
\end{tabular}

(2005) has found appropriate for exploring causal relationships between independent and dependent variables. The details regarding the method of research design, sample, research instruments, the procedure of data collection, and statistical techniques are reported herewith.

\section{Sites and Participants}

The study was conducted among 400 teachers following a heterogeneous purposive sampling technique for giving a representation of maximum geographical locations and demographics of 100 purposively selected Indian secondary schools under the same administrative control of West Bengal Boards of Secondary Education (WBBSE) having an officially established ICT infrastructure. It was purposive sampling because in India ICT use in schools was very limited especially before the COVID-19 pandemic arrival. Hence only those schools were selected having official ICT labs or computers to use for pedagogic purposes. The actual names of the schools and the survey participants were withheld following the research ethics. Detail demographic data of the participants are presented in Table 1.

\section{Research Tools}

Self-efficacy for technology integration scale: It is a standardized widely used scale originally developed by Wang, Ertmer, \& Newby (2004) to measure teachers' perceptions about their confidence that they would be able to integrate technology in the classroom. The scale consists of 21 items, each attached with a five-point Likert scale to quantitatively measure participants' feeling ranging from strongly disagree (0) to strongly agree (5) with higher scores indicating stronger technology integration self-efficacy belief. Since it was a standardized scale, after necessary contextualization and local language (Bengali) translation Face Validity was ascertained taking help of few university 
professors and field experts. Regarding reliability the Internal Consistency Measure (Cronbach's $\alpha$ ) was found .92 which was of excellent degree.

Teachers' perception of ICT infrastructure scale: This scale was developed by the researchers in an earlier study (in Kundu, Bej, \& Dey, 2020) and found effective to explore teachers' perception of ICT infrastructure having acceptable internal consistency 0.87 (Cronbach's $\alpha$ ). Here, three basic domains of ICT infrastructure were selected for the investigation- teacher training aspects, having four question items (No.1-4); ICT equipment aspects, also having four question items (No. 5-8); management roles regarding school policies and implementation mechanism with another four item questions (No. 9-12). A five-point Likert scale was employed to measure each question with higher scores indicating better perception on the item.

Teachers' ability of ICT use scale: We developed this scale taking aids from similar scales especially that of Turel, Ozdemir, \& Elmali (2017) considering the Indian context to measure teachers' perception of few crucial ICT abilities having 30 items divided into two domains with 15 items each- Basic hardware \& software operation and ICT use in instructional design \& delivery. Since it was a newly designed scale, it has been attached in the Appendix to help others belonging to this knowledge society. Each question item is attached with a five-point Likert-type rating ranging from strongly disagree (1) to strongly agree (5) with higher scores indicating stronger ability. Since this was a self-developed scale its Validity was determined through an objective and most authentic Concurrent Validity measure (a type of Criterion validity) by experimentally applying on a limited number (50) of participants and the Pearson Correlation $(r=0.87)$ that was good (as per rule of thumb) in compare to the earlier scale of Turel, Ozdemir, \& Elmali (2017). The internal consistency measure (Cronbach's $\alpha$ ) was .91 which was of excellent degree.

\section{Data Collection}

A pilot version of the surveys was initially administered to a limited number of respondents (fifty) with different characteristics to establish the effectiveness of the designed tools. Testing the survey design helped ensure that the used terms were easily perceived, as well as to check for validity (i.e. the items were asking what we wanted to learn) and consistency. Member checking was also used to check the accuracy of the data collected. Three to four days visit to each school were taken for data collection held in between November 2019 to February 2020 before the pandemic outbreak of the COVID-19 (World Health Organization, 2020) and eventual prolong lockdown. Out of four hundred distributed questionnaire packets we could collect only three hundred in order and considerable for data analysis. The survey response rate was seventy five percent owing to a an ensuing COVID threat.

\section{Data Analysis}

Data were analyzed in accordance with the research approaches and results were presented accordingly in several tables. Descriptive as well as inferential statistics and underlying relationships between the variables were found out by computing appropriate statistics with the help of SPSS-20.0 software. Descriptive statistics (Mean and Std. deviation) were used to evaluate teachers' perceptions of selfefficacy, infrastructure, and ICT ability. The inferential statistics like simple and multiple regression analysis were conducted to deduce a conclusion. Regression analysis is one of the most commonly used statistical techniques in social and behavioral sciences involving identifying and evaluating the relationship between a dependent variable and one or more independent variables (Gallo, 2015). 
Table 2. Descriptive statistics of self-efficacy, infrastructure, and ease of ICT use

\begin{tabular}{|l|l|l|}
\hline Variables $(\mathbf{N}=\mathbf{3 0 0})$ & Mean & Std. Deviation \\
\hline Self-efficacy & 43.82 & 7.05 \\
\hline Perceived infrastructure & 37.32 & 8.02 \\
\hline Perceived ease of ICT use & 75.80 & 10.97 \\
\hline
\end{tabular}

\section{RESULT}

\section{Description of Self-Efficacy, Perceived Infrastructure, and Ease of ICT Use}

Findings regarding the current scenario of ICT self-efficacy among the respondent teachers are presented in Table 2 that shows an overall self-efficacy is of moderate level (Mean=43.82, Std. Deviation=7.05).

The frequency distribution histogram of the self-efficacy scores presented in Figure 2 shows the distribution is slightly positively skewed $(\mathrm{Skp}=0.41)$ that indicates more individuals in the group score less than the average score for their group which is further explained through the Mode score (39). This brings the conclusion that teachers' overall ICT self-efficacy is medium to low as per the measurement scale (Minimum=21, Maximum=105) used in this study.

Findings on the current situation of teachers' perception of ICT infrastructure as evident in Table 2 that shows overall teachers having a moderate perception of ICT infrastructure in their respective institutions (Mean $=37.32$, Std. Deviation $=8.02$ ). The frequency distribution histogram of the ICT infrastructure perception scores presented in Fig. 3 shows that the distribution is slightly negatively skewed $(\mathrm{Skp}=-.38)$ that also indicates there are more individuals in the group who score more than the average mean score for their group. This conveys the implication that respondent teachers' overall perception of ICT infrastructure is medium to slightly high as per the used measurement scale (Minimum possible score $=12$, Maximum possible score $=60$ ).

Findings regarding the present scenario of teachers' ease of ICT use as evolving in Table 2 shows teachers' have moderate level (Mean=75.8, Std. Deviation=10.9) ease with the ICT use. The frequency distribution histogram of the teachers' ease of ICT use scores presented in Fig. 5 shows that the distribution is slightly negatively skewed $(\mathrm{Skp}=-.63)$ that indicates more individuals in

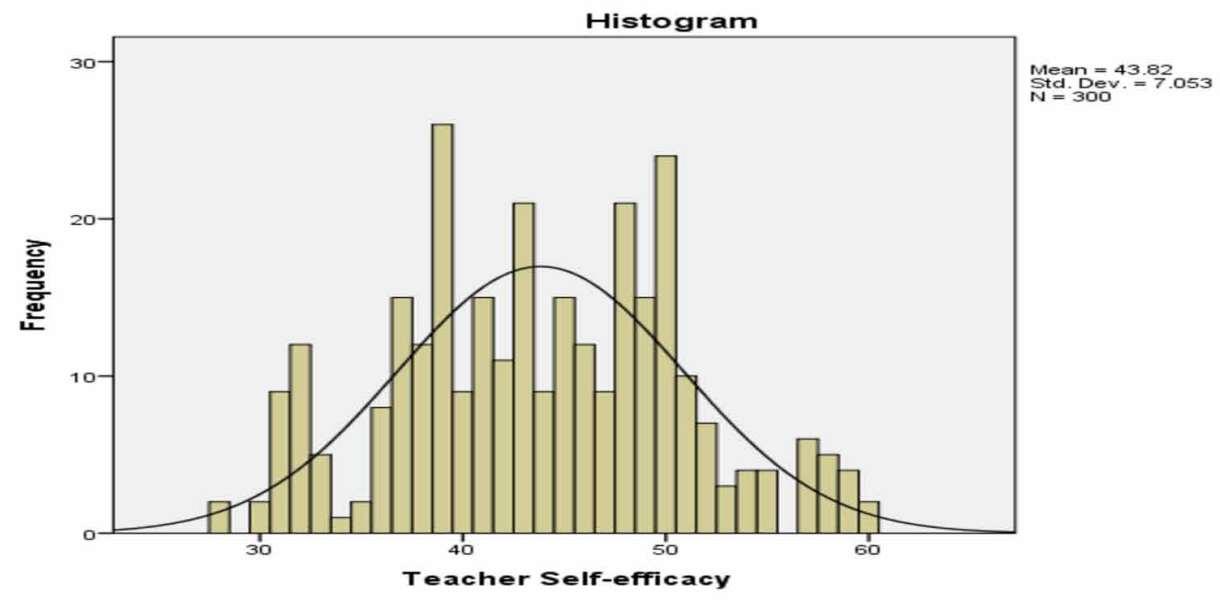




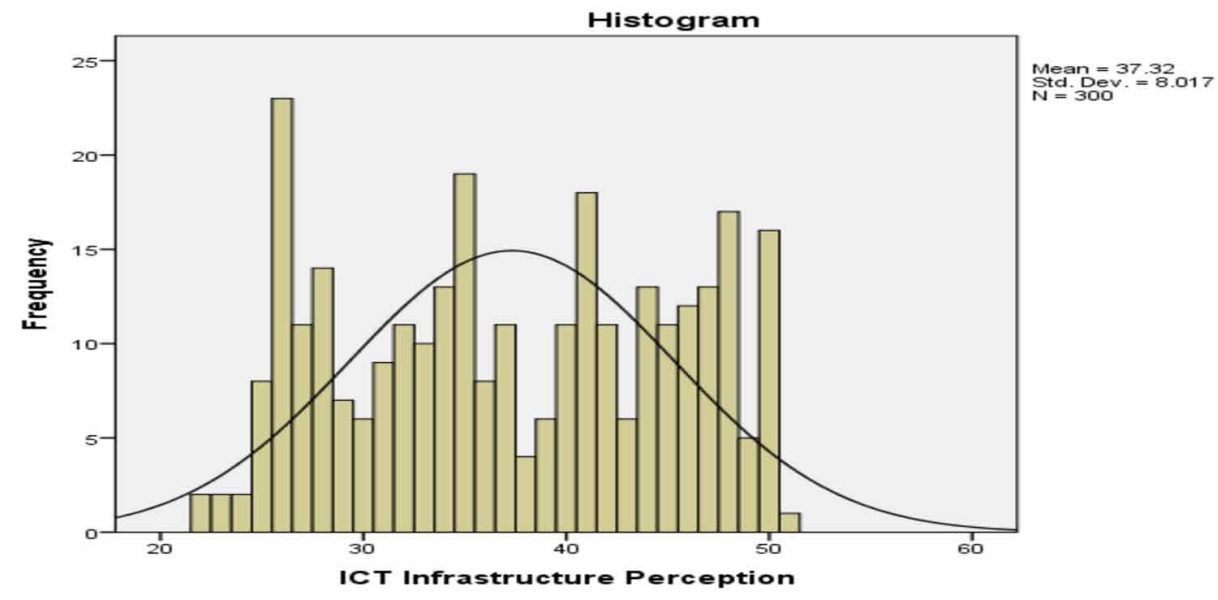

Figure 4. Frequency distribution of perceived ease of ICT use scores

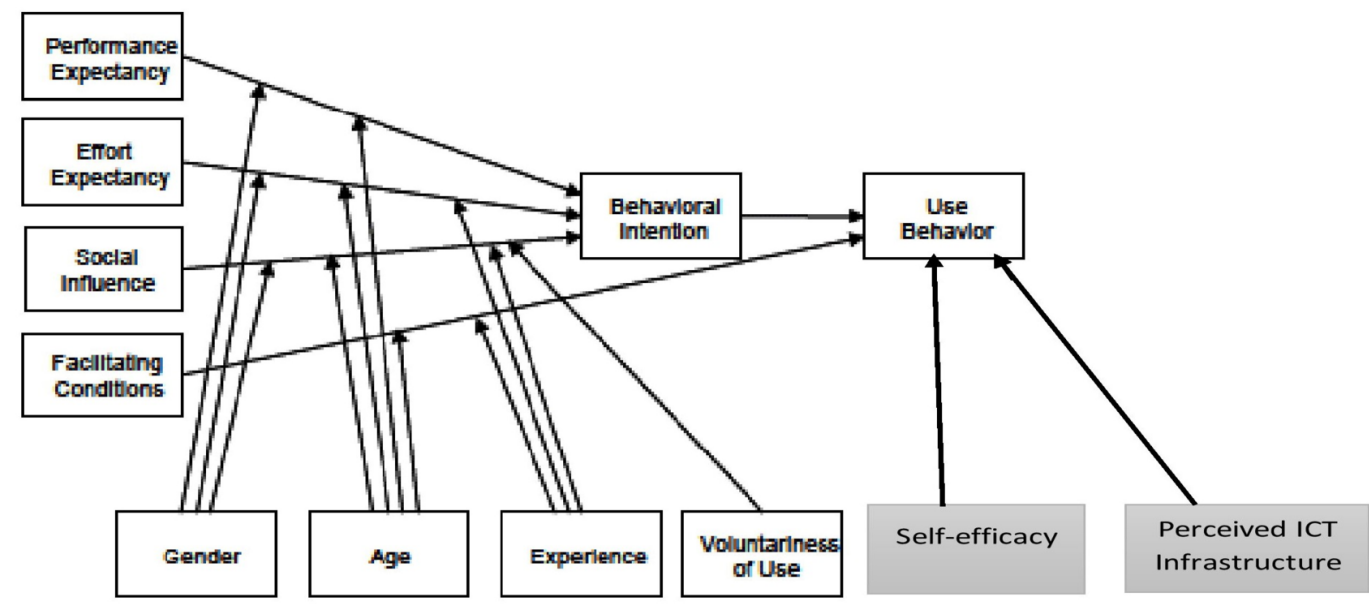

the group score more than the average mean score for their group. This conveys the inference that respondent teachers' overall ease of ICT use is medium to slightly high as per the measurement scale (Minimum=30, Maximum=150) used here.

\section{Findings Regarding the First Null Hypothesis}

To investigate the effect of self-efficacy on teachers' ease of ICT use a simple linear regression was conducted and its summary is presented in Table 3 that shows the effect of self-efficacy on teachers' perceived ease of use is statistically significant and moderate. When self-efficacy is the only predictor the teachers' ICT ability is expected to be affected by following this formula.

[ Ease of ICT use $=[29.36+(.68)$ self-efficacy $]$

When R2 (goodness-of-fit) is .47 indicating the percentage of the variance in the dependent variable that the independent variables explain collectively. Besides, these two variables are having 
Table 3: Summary of simple regression analysis for self-efficacy predicting the ease of ICT use

\begin{tabular}{|c|l|l|l|l|l|l|l|l|l|}
\hline $\begin{array}{c}\text { Sl. } \\
\text { No. }\end{array}$ & \multicolumn{1}{|c|}{ Predictors } & \multicolumn{1}{|c|}{$\mathbf{R}$} & \multicolumn{1}{|c|}{$\mathbf{R}^{2}$} & \multicolumn{1}{|c|}{$\mathbf{F}(\mathbf{1 , 2 9 8})$} & \multicolumn{1}{|c|}{ Sig. } & \multicolumn{1}{|c|}{$\mathbf{B}$} & $\boldsymbol{\beta}$ & \multicolumn{1}{|c|}{$\mathbf{p}$} & p \\
\hline & & .68 & .47 & $258.54^{*}$ & $0.000^{*}$ & - & - & - & - \\
\hline & Constant & - & - & - & - & 29.36 & - & 10 & $.000^{*}$ \\
\hline 1 & Self-efficacy & - & - & - & - & 1 & .68 & 16 & $.000^{*}$ \\
\hline
\end{tabular}

a high positive correlation among them exemplified by the $\mathrm{R}(.68)$. Hence the 1 st null hypothesis is rejected. In Table 3, the beta coefficient $(\beta)$, or the degree of change in the outcome variable for every one unit of change in the predictor variable, is +0.68 which means for 1 standard unit increase in self-efficacy, the perceived ease of ICT use will increase by 0.68 standard unit.

\section{Findings Regarding the Second Null Hypothesis}

Investigating the effect of infrastructure perception on teachers' ease of ICT use another simple linear regression was conducted and the result summary is presented in Table 4 that shows the effect of infrastructure on teachers' ease of use is also statistically $(\mathrm{R} 2=79, \mathrm{P}<.05)$ significant and when infrastructure perception is the only predictor, the teachers' ease of use is expected to be affected as per the following formula:

[ ICT ability $=[30.3+(0.89)$ infrastructure perception $]$

When R2 (goodness-of-fit) is .79 indicating the percentage of the variance in the dependent variable that the independent variables explain collectively. These two variables are also having a very high positive correlation among them exemplified through $\mathrm{R}(.89)$. The 2 nd null hypothesis is also

Table 4: Simple regression for ICT infrastructure predicting teachers' ease of ICT

\begin{tabular}{|c|l|l|l|l|l|l|l|l|l|}
\hline $\begin{array}{c}\text { SI. } \\
\text { No. }\end{array}$ & \multicolumn{1}{|c|}{ Predictors } & \multicolumn{1}{|c|}{$\mathbf{R}$} & \multicolumn{1}{|c|}{$\mathbf{R}^{\mathbf{2}}$} & \multicolumn{1}{|c|}{$\mathbf{F}(\mathbf{1 , 2 9 8})$} & \multicolumn{1}{|c|}{ Sig. } & \multicolumn{1}{|c|}{$\mathbf{B}$} & $\boldsymbol{\beta}$ & \multicolumn{1}{|c|}{} & p \\
\hline & & .89 & .79 & $610.97^{*}$ & $0.000^{*}$ & - & - & - & - \\
\hline & Constant & - & - & - & - & 30.3 & - & 22.08 & $.000^{*}$ \\
\hline 1 & ICT Infrastructure & - & - & - & - & 1.22 & .89 & 33.91 & $.000^{*}$ \\
\hline
\end{tabular}

hereby rejected and it can be claimed there is a substantial effect $(\mathrm{R} 2=.79)$ that for 1 standard unit increase in perceived infrastructure, the perceived ease of ICT use will increase by 0.89 standard unit.

\section{Findings Regarding the Third Null Hypothesis}

Regarding this main research question that is an investigation of the combined effects of self-efficacy and perceived ICT infrastructure on the teachers' ease of ICT use, a multiple linear regression was conducted and the model summary of which is presented in Table 5.

The above multiple regression analysis is highly significant with $(\mathrm{p}<<.05)$ which means the regression model is effective and 80 percent of the dependent variable is significantly affected by the combined influence of the independent variables $(\mathrm{R} 2=.80)$. The coefficient results show the effects of each of the independent variables on the dependent variable. It is evident that self-efficacy made a statistically significant individual contribution to this mutual prediction of the teachers' ICT useability 
Table 5: Multiple regression for self-efficacy and infrastructure predicting on ease of use

\begin{tabular}{|l|l|l|l|l|l|l|l|l|l|}
\hline $\begin{array}{c}\text { Sl. } \\
\text { No. }\end{array}$ & \multicolumn{1}{|c|}{ Predictors } & \multicolumn{1}{|c|}{$\mathbf{R}$} & \multicolumn{1}{|c|}{$\mathbf{R}^{2}$} & \multicolumn{1}{|c|}{$\mathbf{~ ( 2 , 2 9 7 )}$} & \multicolumn{1}{|c|}{ Sig. } & \multicolumn{1}{|c|}{$\mathbf{B}$} & $\boldsymbol{\beta}$ & \multicolumn{1}{|c|}{ t } & p \\
\hline & & .9 & .8 & $610.97^{*}$ & $0.000^{*}$ & - & - & - & - \\
\hline & Constant & - & - & - & - & 25.69 & - & 14.5 & $.000^{*}$ \\
\hline 1 & Self-efficacy & - & - & - & - & .22 & .14 & 3.9 & $.000^{*}$ \\
\hline 2 & ICT Infrastructure & & & & & 1.09 & .8 & 22.7 & $.000^{*}$ \\
\hline
\end{tabular}

Figure 5. Scatter plot analysis of the multiple regression

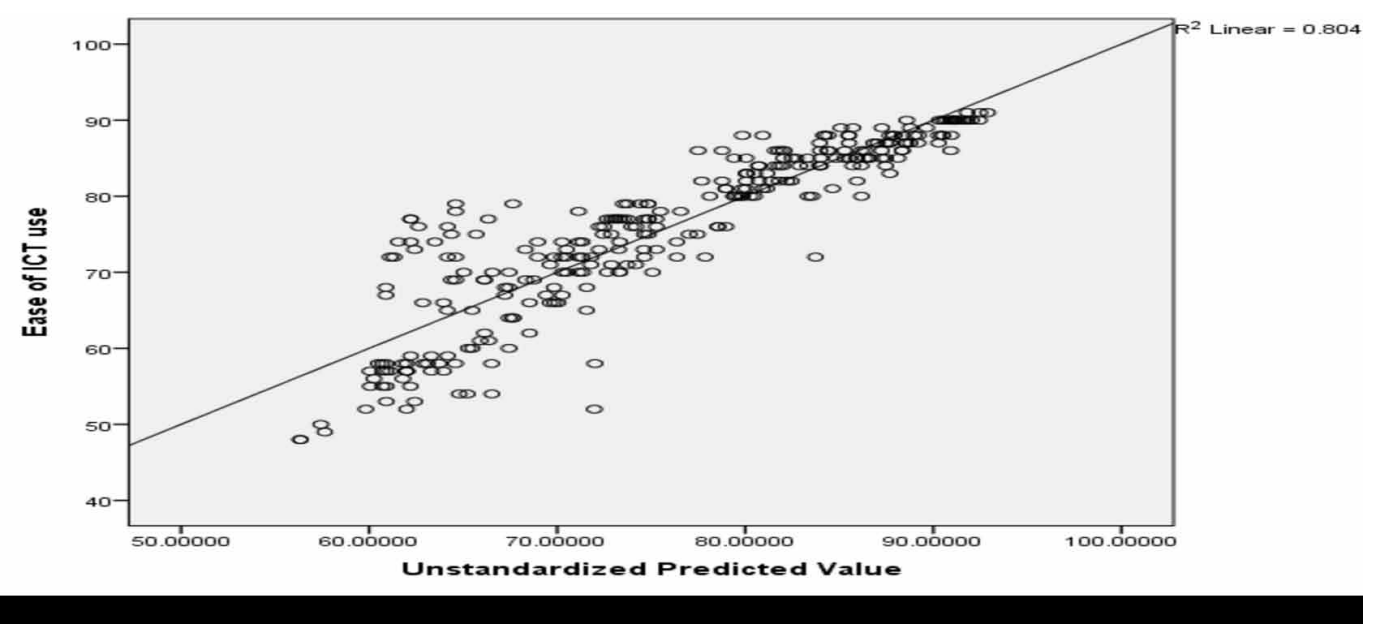

$(\beta=.14, \mathrm{t}=3.9, \mathrm{p}<.05)$. On the other hand, ICT infrastructure is also found to have a statistically significant individual contribution to the prediction of the teachers' ICT useability $(\beta=.8, \mathrm{t}=22.7$, $\mathrm{p}<.05)$. Based on this outcome the following regression equation is evolved:

[ Ease of ICT use $=[25.69+(0.14)$ self-efficacy $+(.8)$ perceived infrastructure $]$

There is a very strong (0.94) positive effect is found between the dependent variable and the two independent variables. For every 1 standard unit simultaneous increase self-efficacy and perceived infrastructure each, the perceived ease of ICT use will increase by 0.94 standard units. A scatter plot analysis of this regression is presented in Fig. 6 that also exhibits data somewhat follow a linear path and the linear pattern is well evident meaning there is a high linear correlation among the variables. The uphill pattern as you move from left to right indicates a positive relationship between the dependent and the independent variables meaning teachers' ICT ability is expected to increase with the increase in their ICT self-efficacy and allied ICT infrastructure.

\section{DISCUSSION}

The main objective of this study was to find out the combined predictions of teachers' ICT self-efficacy and allied infrastructure on their ability to use ICT, at the same time to investigate the individual effects of the predictor variables on the dependent variable. Findings revealed a strong and statistically significant combined prediction of self-efficacy $(\beta=.138, \mathrm{t}=3.9, \mathrm{p}<.05)$ and allied ICT infrastructure 
Figure 6. Final outcome of the proposed research model

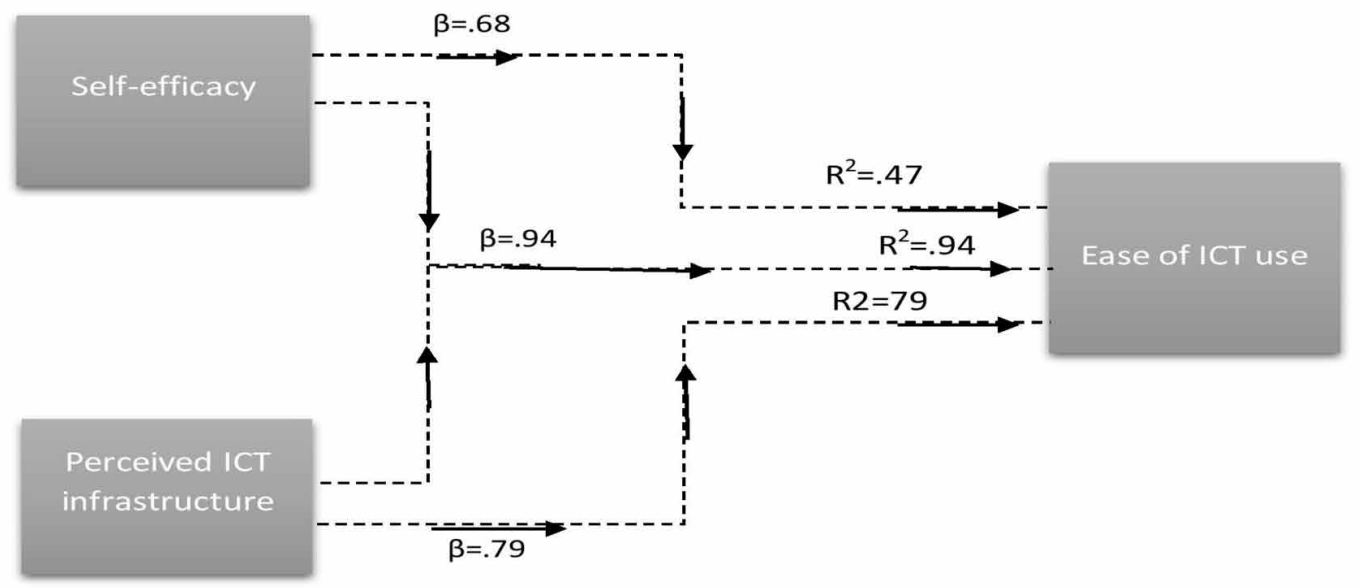

$(\beta=.8, \mathrm{t}=22.7, \mathrm{p}<.05)$ on the teachers' ability of ICT use. Both the independent variables were effective in predicting the dependent variable and this prediction encompasses 80 percent of the variance in the dependent variable is explained by the independent variables. This combined effect is more influential than their individual effects- self-efficacy (with 47 percent prediction) and ICT infrastructure perception (with 79 percent prediction). Thus, when these two variables are operative simultaneously, they bring out a better prediction of the teachers' ability. The consequences of the proposed structural equation model after analysis thus comes out as follows (see Fig. 6).

Based on this outcome the authors proposed an extension of the Unified Theory of Acceptance and Use of Technology (UTAUT) model towards UTAUT+ by adding two new factors users' selfefficacy and infrastructure perception having a substantial effect on their ease of technology use. The proposed UTAUT+ has been presented in Fig. 8.

The model (Fig.8) shows self-efficacy being a part of users' internal cognitive domain behind ICT integration affects user's ease of ICT use significantly and the degree of prediction is evident from Table 5 and in Fig. 6. This finding corroborates the outcomes of past studies already discussed in the literature (e.g., Erdogan, 2011; Harding, 2012; Badia et al., 2013; Oye et al., 2014; TschannenMoran \& Hoy, 2001; Pumptow \& Brahm, 2020; Hatlevik \& Hatlevik, 2018; Hong, Hwang, Tai, \& Lin, 2017; Vayre \& Vonthron, 2016; Oye et al., 2014; Al-Ruz \& Khasawneh, 2011; Chen, 2008; Lin, Wang \& Lin, 2012; Sang et al., 2011; Bandura, 1997; Fanni et al., 2013; Teo, 2014; Hatlevik, 2017; Krumsvik, 2014; Teo et al. 2008; Lai \& Pratt, 2004; Krumsvik, 2014) that self-efficacy is effective in inspiring users' ICT use.

Similarly, user's perception of ICT infrastructure as an external factor behind ICT use also affects significantly their ease of ICT usage and the degree of prediction is evident in Table 5 and Fig. 6. This finding also goes in line with several past studies already discussed in the previous sections (e.g., Samuel \& Bakar, 2006; Afshari, Bakar, Luan, Samah, \& Fooi, 2008; Ali, Nor, Hamzah, \& Alwi, 2009; Vanderlinde \& van Braak, 2010; Moses, Bakar, Mahmud \& Wong, 2016; Shiue, 2007; Cowie \& Jones, 2005; Moses, Bakar, Mahmud \& Wong, 2016) that claimed infrastructure as a key factor behind that effect users' ICT usage. But their combined effect is a unique discovery in the current study that has found more potent to predict user's ICT usage than their potential individual effects. The degree of prediction in this case as found in Table 5 and in Fig.6 is very strong (0.94) and for every 1 standard unit simultaneous increase self-efficacy and perceived infrastructure each, the perceived ease of ICT usage will increase by 0.94 standard unit. 


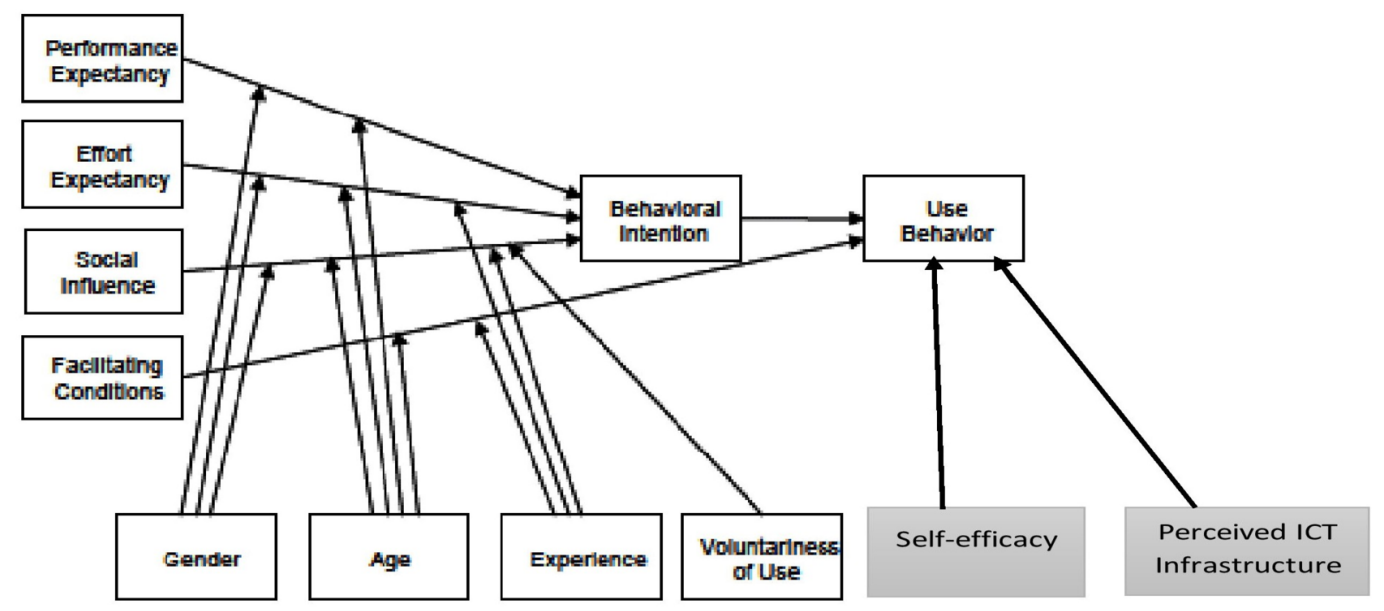

The results of this investigation also revealed few contextual truths that Indian secondary school teachers' ICT self-efficacy was found moderate to a low level which means they lack the necessary confidence and beliefs within themselves in using ICT. Since teacher's belief or his teaching efficacy about teaching-learning in general, play a very crucial role as claimed by several authors and since it determines whether the teacher will adopt and use the available ICT resources in the classroom to make his teaching effective but its low level among teachers is bound to put a negative impact on the effective integration of ICT in the school pedagogy. Further, teachers also held a moderate perception regarding ICT infrastructure in their respective schools, and their ability to use ICT in pedagogy was also found to a moderate degree. This moderate perception of infrastructural facilities was also bound to hamper an effective pedagogical integration of ICT and this poor infrastructural situation in the country has already been mentioned as an alarming concern in several past studies (e.g., Thirumurthy \& Sundaram, 2003; Bharadwaj, 2007; Gupta \& Haridas, 2012; Prasad, 2013; Kundu \& Dey, 2018; Kundu, 2018; Bindu, 2019; Kaur, 2019; Singhavi \& Basargekar, 2019; EQFI, 2015). All these deficiencies culminate in the poor ICT use abilities on the parts of the teachers and it has become evident more than ever in the current COVID pandemic era highlighting the skeletal picture of ICT integrated pedagogy in India (Kundu \& Bej, 2020). It has not only been hampering the implementation of 21 st-century modern pedagogy but also depriving students of the quality learning experience as several studies claimed (e.g., Bakar, Ayub, Luan, \& Tarmizi, 2010; Yee, Luan, Ayub, \& Mahmud, 2009; Chen, 2007; Luan, Atan, \& Sabudin, 2010; Kozma, 2008; Ghavifekr, Abd Razak, Ghani, Ran, Meixi, \& Tengyue; 2014; Nkula \& Krauss, 2014).

\section{IMPLICATION, LIMITATIONS, AND FUTURE SCOPE}

ICT use for pedagogical purposes has always been a difficult task. It has become more difficult for the aged teachers who taught themselves in the traditional classrooms with teacher-dominated pedagogy (Kundu, 2018b). But it has become a necessity for today's fast-changing interactive world where the students' individuality and innate creativities are judiciously aimed to cultivate (Kundu, 2020). Teachers' roles have been limited by the use of mechanical and digital technologies that need to be understood by the teaching fraternity. They need to uprise their ability of ICT use irrespective of difficulties. In this context, the outcomes of this study will add to the counseling process for the teachers to prepare them internally with a strong base of self-belief. At the same time ICT and allied infrastructure need to make stronger because this study empirically proved that teachers' perception 
of infrastructure has a very strong positive correlation with their ease of technology usage. This will, in turn, help in the planning of ICT integrated school pedagogy since enhancing teachers' ability is the target to policy-making bodies which in turn will benefit the students' potential for proposed achievement. Besides the regression equation evolved in this study may serve as a ready reference showing quantitively how much efficacy and infrastructure perception are potent to add to the ICT usage among teachers. The outcome is further explained with a model (see Fig. 6) that is also a significant contribution of this study towards claiming an extension of the UTAUT model. The proposed extension UTAUT+ has been presented in Fig.7 which is an exclusive addition to the existing literature. The exclusive scale to measure users' ease of ICT usage developed in course of this study is also a meaningful contribution to the upcoming generations of scholars.

So far as limitations are concerned the study was conducted in a particular region of India and the collected data were generalized. The contextual limitations may affect the results. Besides the sample size was only four hundred but we could collect only three hundred responses in order owing to ensuing COVID outcome and school closure. Naturally, the results could show deviations among a larger sample size. Despite that, the study left before the researchers with a light of hope and aspiration to study other unreached factors of ICT integration, both internal and external, as mentioned earlier in this study like self-concept, self-esteemed, creativity, management, governmental supports, etc. and investigate their effects on the teachers' ability of ICT use.

\section{CONCLUSION}

This current study concluded with this note that the teachers' self-efficacy and perception of infrastructure have a statistically significant effect on their ease of ICT use. This outcome supports the previous claim in the UTAUT that behavioral intentions coupled with positive facilitating conditions can contribute to teachers' ICT usage. Both predictors are also found to have significant individual predictions over the dependent variable that is teachers' ease of ICT use wherefrom the authors proposed UTAUT + . All these hold with high expectations that the study will put a meaningful contribution to the planning and execution of technology-integrated educational policies in any country, especially to those developing ones, to enhance their teachers' ease of technology use in pedagogy during a post COVID era of new normal.

\section{RECOMMENDATIONS}

Based on the outcomes of the study, the researchers proposed the following recommendations for the effective use of ICT in school pedagogy by increasing teachers' self-efficacy and perception of infrastructure. To enhance teachers' self-efficacy apposite training and toolkits need to be developed. It's possible to enhance as shown in several past studies like Kundu (2020) manipulating the prescribed sources in Bandura (1997). Secondly, ICT infrastructure is also found to have a stronger effect on the teachers' ease of usage. Hence, planning for infrastructural development in both aspects-technical support and management support- is a prerequisite to enhance teachers' ICT usability. 


\section{REFERENCES}

Abu Al-ruz, J., \& Khasawneh, S. (2011). Jordanian Pre-Service Teachers' and Technology Integration: A Human Resource Development Approach. Journal of Educational Technology \& Society, 14, 77-87.

Afshari, M., Bakar, K. A., Luan, W. S., Samah, B. A., \& Fooi, F. S. (2008). School leadership and information communication technology. The Turkish Online Journal of Educational Technology, 7(4), 82-91.

Albirini, A. (2006). Teachers' attitudes toward information and communication technologies: The case of Syrian EFL teachers. Computers \& Education, 47(4), 373-398. doi:10.1016/j.compedu.2004.10.013

Aldunate, R., \& Nussbaum, M. (2013). Teacher adoption of technology. Computers in Human Behavior, 293(3), 519-524. doi:10.1016/j.chb.2012.10.017

Ali, W. A. W., Nor, H. M., Hamzah, A., \& Alwi, H. (2009). The conditions and level of ICT integration in Malaysian Smart Schools. International Journal of Education and Development using ICT, 5(2), 1-7.

Anderson, J., \& van Weert, T. (Eds.). (2002). Information and Communication Technology in Education: A Curriculum for Schools and Programme of Teacher Development. United Nations Educational Scientific and Cultural Organization, Division of Higher Education, UNESCO.

Anderson, S. E., \& Maninger, R. M. (2007). Preservice Teachers' Abilities, Beliefs, and Intentions regarding Technology Integration. Journal of Educational Computing Research, 37(2), 151-172. doi:10.2190/H1M8562W-18J1-634P

Badia, A., Meneses, J., \& Sigalès, C. (2013). Teacher's perceptions of factors affecting the educational use of ICT in technologyrich classrooms. Electronic Journal of Research in Educational Psychology, 11(3), 786-808.

Balanskat, A., Blamire, R., \& Kefala, S. (2006). A review of studies of ICT impact on schools in Europe. European Schoolnet.

Bandura, A. (1993). Perceived Self-Efficacy in Cognitive Development and Functioning. Educational Psychologist, 28(2), 117-148. doi:10.1207/s15326985ep2802_3

Bandura, A. (1997). Self-efficacy: The exercise of control. W H Freeman/Times Books/Henry Holt \& Co.

Bandura, A., Barbaranelli, C., Caprara, G. V., \& Pastorelli, C. (2001). Self-Effi cacy Beliefs as Shapers of Children's Aspirations and Career Trajectories. Child Development, 72(1), 187-206. doi:10.1111/14678624.00273 PMID:11280478

Banoglu, K., Vanderlinde, R., \& Yildiz, R. (2015). Professional self-efficacy scale for information and computer technology teachers: Validity and reliability study. Anthropologist, 20(1-2), 22-32. doi:10.1080/09720073.20 15.11891720

Baylor, A. L., \& Ritchie, D. (2002). What factors facilitate teacher skill, teacher moral, and perceived student learning in technology using classroom. Computers \& Education, 39(2), 395-414. doi:10.1016/S03601315(02)00075-1

Bharadwaj, V. (2007). ICT usage in 1000 schools in India. Digital Learning, 3(11), 8-15.

Bindu, C. N. (2019). Barriers to ICT Integration in teaching: A case study of teachers in Kerala. http:// educationindiajournal.org/home_art_avi.php?path=\&id=351\#

Butcher, N., Moore, A., \& Hoosen, S. (2014). Harnessing OER to Develop Teachers: The Guyana Experience. https://files.eric.ed.gov/fulltext/EJ1106066.pdf

Caprara, G. V., Barbaranelli, C., Steca, P., \& Malone, P. S. (2006). Teachers' self-efficacy beliefs as determinants of job satisfaction and students' academic achievement: A study at the school level. Journal of School Psychology, 44(2006), 473-490. doi: .09.00110.1016/j.jsp.2006

Chai, C. S., Hong, H. Y., \& Teo, T. (2009). Singaporean and Taiwanese pre-service teachers' beliefs and their attitude towards ICT: A Comparative Study. The Asia-Pacific Education Researcher, 18, 117-128.

Chen, Y. L. (2007). Modeling the determinants of internet use. Computer Education, 51(2), 545-558. doi:10.1016/j.compedu.2007.06.007 
Chigona, A. (2015). Pedagogical shift in the twenty-first century: Preparing teachers to teach with new technologies. Africa Education Review, 12(3), 478-492. doi:10.1080/18146627.2015.1110912

Chigona, A. (2015a). Teacher education students' domestication of ICTs for teaching and learning. In Global Learn (pp. 240-247). Association for the Advancement of Computing in Education (AACE).

Chou, C. (2003). Interactivity and interactive functions in web-based learning system-a technical framework for designers. British Journal of Educational Technology, 34(3), 265-279. doi:10.1111/1467-8535.00326

Christophersen, K. A., Elstad, E., Turmo, A., \& Solhaug, T. (2016). Teacher education programmes and their contribution to student teacher efficacy in classroom management and pupil engagement. Scandinavian Journal of Educational Research, 60(2), 240-254. doi:10.1080/00313831.2015.1024162

Compeau, D. R., \& Higgins, C. A. (1995). Computer self-efficacy: Development of a measure and initial test. Management Information Systems Quarterly, 19(2), 189-211. doi:10.2307/249688

Cowie, B., \& Jones, A. (2005). Digital horizons: Laptop for teachers evaluation study update on secondary teacher's experiences. Retrieved October 30, 2007 from http://www.minedu.govt.nz/web/downloadable/ d18568_v1/laptop-leaders-report-12-9-with-edits-ds.doc

Creswell, J. W. (2005). Educational research: Planning, conducting, and evaluating quantitative and qualitative research (2nd ed.). Pearson.

Davis, F. (1989). Perceived Usefulness, Perceived Ease of Use, and User Acceptance of Information Technology. Management Information Systems Quarterly, 13(3), 319-340. doi:10.2307/249008

Davis, N. E., \& Tearle, P. (1999). A core curriculum for telematics in teacher training. Available: www.ex.ac. uk/telematics.T3/corecurr/tteach98.htm

Dexter, S. L., Anderson, R. E., \& Ronnkvist, A. M. (2002). Quality technology support: What is it? Who is it? And what differences does it make? Journal of Educational Computing Research, 26(3), 265-285. doi:10.2190/ WFRB-PE10-WAMJ-G2P1

Erdogan, T. (2011). Factors that influence pre-service teachers' ICT usage in education. European Journal of Teacher Education, 34(4), 483-499. doi:10.1080/02619768.2011.587116

Ertmer, P. (2005). Teacher pedagogical beliefs: The fi nal frontier in our quest for technology integration. Educational Technology Research and Development, 53(4), 25-39. doi:10.1007/BF02504683

Ertmer, P. A., \& Ottenbreit-Leftwich, A. T. (2010). Teacher technology change. Journal of Research on Technology in Education, 42(3), 255-284. doi:10.1080/15391523.2010.10782551

Fanni, F., Rega, I., \& Cantoni, L. (2013). Using self-efficacy to measure primary school teachers' perception of ICT: Results from two studies. Int. J. Educ. Dev. Inform. Commun. Technol., 9, 100-111.

Fathema, N., Shannon, D., \& Ross, M. (2015). Expanding the Technology Acceptance Model (TAM) to Examine Faculty Use of Learning Management Systems (LMSs) In Higher Education Institutions. Journal of Online Learning and Teaching, 11, 210-233.

Flanagan, L., \& Jacobsen, M. (2003). Technology Leadership for the Twenty- first Century Principal. Journal of Educational Administration, 41(2), 124-142. doi:10.1108/09578230310464648

Fredriksson, U., Jedeskog, G., \& Plomb, T. (2008). Innovative use of ICT in schools based on the findings in ELFE project. Education and Information Technologies, 13(2), 83-101. doi:10.1007/s10639-007-9054-4

Frost \& Sullivan. (2006). Impact assessment study on the smart school integrated solution (SSIS) and other ICT initiatives. Commissioned by MSC Malaysia and Ministry of Education.

Gallo, A. (2015). A Refresher on Regression Analysis. Harvard Business School. https://hbr.org/2015/11/arefresher-on-regression-analysis

Ghavifekr, S., Abd Razak, A. Z., Ghani, M. F. A., Ran, N. Y., Meixi, Y., \& Tengyue, Z. (2014). ICT Integration In Education: Incorporation for Teaching \& Learning Improvement. Malaysian Online Journal of Educational Technology, 2(2), 24-46. 
Guo, Y., Connor, C. M., Yang, Y., Roehrig, A. D., \& Morrison, F. J. (2012). The effects of teacher qualification, teacher self-efficacy, and classroom practices on fifth graders' literacy outcomes. The Elementary School Journal, 113(1), 3-24. doi:10.1086/665816

Guoyuan, S., Valcke, M., van Braak, J., Tondeur, J., \& Zhu, C. (2011). Predicting ICT integration into classroom teaching in Chinese primary schools: Exploring the complex interplay of teacher-related variables. Journal of Computer Assisted Learning, 27(2), 160-172. doi:10.1111/j.1365-2729.2010.00383.x

Gupta, C., \& Haridas, K. (2012). Role of ICT in Improving the Quality of School Education in Bihar (working paper). Retrieved from IGC international Growth Centre website https://www.theigc.org/wp-content/ uploads/2014/09/Das-Gupta-KPN-2012-Working-Paper.pdf

Hammond, M., Reynolds, L., \& Ingram, J. (2011). How and why do student teachers use ICT? Journal of Computer Assisted Learning, 27(3), 191-203. doi:10.1111/j.1365-2729.2010.00389.x

Harding, R. D. (2012). Policy Brief: Quality Management and Assurance in ICT-Integrated Pedagogy. In Policy Brief. UNESCO Institute for Information Technologies in Education.

Haslaman, T., Mumcu, F. K., \& Usluel, Y. K. (2008). Integration of ICT Into The Teaching-Learning Process: Toward A Unified Model. In Proceedings of World Conference on Educational Multimedia, Hypermedia and Telecommunications 2008 (pp. 2384-2389). Chesapeake, VA: AACE.

Hatlevik, I., \& Hatlevik, O. (2018). Examining the Relationship Between Teachers' ICT Self-Efficacy for Educational Purposes, Collegial Collaboration, Lack of Facilitation and the Use of ICT in Teaching Practice. Frontiers in Psychology, 9, 935. doi:10.3389/fpsyg.2018.00935 PMID:29951018

Hatlevik, O. E. (2017). Examining the relationship between teachers' self-efficacy, their digital competence, strategies to evaluate information, and use of ICT at school. Scand. J. Educ. Res. 61, 555-567. doi: $.117250110 .1080 / 00313831.2016$

Hong, J. C., Hwang, M. Y., Tai, K. H., \& Lin, P. H. (2017). Intrinsic motivation of Chinese learning in predicting online learning self-efficacy and flow experience relevant to students' learning progress. Computer Assisted Language Learning, 30(6), 552-574. doi:10.1080/09588221.2017.1329215

Hong, J.-Y. (2012). Why do some beginning teachers leave the school, and others stay? Understanding teacher resilience through psychological lenses. Teach. Teach. Theory Pract., 18(4), 417-440. doi:10.1080/13540602 .2012 .696044

Honicke, T., \& Broadbent, J. (2016). The Influence of Academic Self-Efficacy on Academic Performance: A Systematic Review. Educational Research Review, 17, 63-84. doi:10.1016/j.edurev.2015.11.002

Klassen, R. M., \& Chiu, M. M. (2011). The occupational commitment and intention to quit of practicing and pre-service teachers: Influence of self-efficacy, job stress, and teaching context. Contemporary Educational Psychology, 36(2), 114-129. doi:10.1016/j.cedpsych.2011.01.002

Koehler, M., \& Mishra, P. (2009). What is technological pedagogical content knowledge (TPACK)? Contemporary Issues in Technology \& Teacher Education, 9(1), 60-70.

Kozma, R. (2003). Technology, innovation, and educational change: A global perspective. Eugene, OR: International Society for Technology in Education (ISTE).

Kozma, R. (2008). Comparative analyses of policies for ICT in education. In J. Voogt \& G. Knezek (Eds.), International handbook of information technology in education (pp. 1083-1096). Springer Science.

Krumsvik, R. J. (2014). Teacher educators' digital competence. Scandinavian Journal of Educational Research, 58(3), 269-280. doi:10.1080/00313831.2012.726273

Krysa, R. (1998). Factors affecting the adoption and use of computer technology in schools. Retrieved April 15, 2008 from http://www.usask.ca/education/coursework/802papers/krysa/krysa.PDF

Kubiatko, M. (2013). The comparison of different age groups on the attitudes toward and the use of ICT. Educational Sciences: Theory and Practice, 13(2), 1263-1272.

Kundu, A. (2018a). Blended Learning in Indian Elementary Education: Problems and Prospects. Journal of Online Learning Research, 4(2), 199-227. Available at. https://www.learntechlib.org/primary/p/180971/ 
Kundu, A. (2018b). A Study on Indian Teachers' Roles and Willingness to Accept Education Technology. International Journal of Innovative Studies in Sociology and Humanities, 3(9). Available at: https://ijissh.org/ articles/2018-2/volume-3-issue-9/

Kundu, A. (2020). A Sound Framework for ICT Integration in Indian Teacher Education. International Journal of Teacher Education and Professional Development, 4(1), 4. Advance online publication. doi:10.4018/IJTEPD

Kundu, A. \& Bej, T. (2020). COVID-19 Response: Students' Readiness for Shifting Classes Online. Corporate Governance: The International Journal of Business in Society. 10.1108/CG-09-2020-0377

Kundu, A. \& Bej, T. (2020a). COVID-19 Response: Students' Readiness for Shifting Classes Online. Corporate Governance: The International Journal of Business in Society. 10.1108/CG-09-2020-0377

Kundu, A., \& Bej, T. (2020b). Ingestion and integration of ICTs for pedagogy in Indian private high schools. E-Learning and Digital Media. Advance online publication. doi:10.1177/2042753020957493

Kundu, A., \& Bej, T. (2021). COVID 19 Response: An analysis of teachers' perception on pedagogical successes and challenges of digital teaching practice during new normal. Education and Information Technologies. Advance online publication. doi:10.1007/s10639-021-10503-5 PMID:33897267

Kundu, A., Bej, T. \& Dey, K.N. (2020). An empirical study on the correlation between teacher efficacy and ICT infrastructure. International Journal of Information and Learning Technology. 10.1108/IJILT-04-2020-0050

Kundu, A., Bej, T., \& Dey, K. N. (2021). Time to achieve: Implementing blended learning routines in an Indian elementary classroom. Journal of Educational Technology Systems, 49(4), 405-431. Advance online publication. doi: $10.1177 / 0047239520984406$

Kundu, A., Bej, T., \& Rice, M. (2020). Time to Engage: Implementing Math and Literacy Blended Learning Routines in an Indian Elementary Classroom. Education and Information Technologies. Advance online publication. doi:10.1007/s10639-020-10306-0

Kundu, A., \& Dey, K. N. (2018a, April-June). Barriers to Utilizing ICT in Education in India with a Special Focus on Rural Areas. International Journal of Scientific Research and Reviews, 7(2), 341-359. www.ijsrr.org/down_933.php

Kundu, A., \& Dey, K. N. (2018b). A Contemporary Study on the Flourishing E-Learning Scenarios in India. International Journal of Creative Research Thoughts, 6(2), 384-390. Available at: https://www.ijcrt.org/ IJCRT1892060.pdf

Lai, K. W., \& Pratt, K. (2004). Information and communication technology (ICT) in secondary schools: The role of the computer coordinator. British Journal of Educational Technology, 35(4), 461-475. doi:10.1111/j.00071013.2004.00404.x

Li, S. (2015). Understanding factors affecting primary school teachers' use of ICT for student centered education in Mongolia (Master Thesis). Tokyo Institute of Technology.

Lin, J., Wang, P.-Y., \& Lin, I.-C. (2012). Pedagogy * technology: A two-dimensional model for teachers' ICT integration. British Journal of Educational Technology, 43(1), 97-108. doi:10.1111/j.1467-8535.2010.01159.x

Luan, W. S., Atan, H., \& Sabudin, S. (2010). Exploring teachers' perceptions of their pedagogical role with computers: A case study in Malaysia. Procedia: Social and Behavioral Sciences, 2(2), 388-391. doi:10.1016/j. sbspro.2010.03.031

Mdlongwa, T. (2012). Information and communication technology as a means of enhancing education in schools in South Africa: Challenges, benefits and recommendations. Policy brief: Africa institute of South Africa, briefing number 80 .

MHRD. (2012). National Policy on ICT in School Education. Retrieved from- https://mhrd.gov.in/sites/upload_files/ mhrd/files/upload_document/revised_policy\%20document\%20ofICT.pdf

Minty, R., \& Pather, E. U. (2014). The integration of ICTs in the teaching and learning of Mathematical Literacy: A study conducted in eight schools in Gauteng, South Africa. International Journal of Science, Commerce and Humanities, 2(1), 47-60.

Moses, Mahmud, \& Wong. (2012). ICT infrastructure, technical and administrative support as correlates of teachers' laptop use. Procedia - Social and Behavioral Sciences, 59, 709 - 714. doi:10.1016/j.sbspro.2012.09.335 
Musharraf S, Bauman S, Anis-Ul-Haque M, \& Malik JA. (2018). Development and Validation of ICT SelfEfficacy Scale: Exploring the Relationship with Cyberbullying and Victimization. Int J Environ Res Public Health. 14;15(12):2867. doi: 10.3390/ijerph15122867.

Moses, P., Khambari, M. N., \& Luan, W. S. (2008). Laptop use and its antecedents among educators: A review of literature. European Journal of Soil Science, 7(1), 104-114.

Ndlovu, N. S., \& Lawrence, D. (2012). Strategies to overcome poverty and inequality: the quality of ICT use in South African classrooms. Paper presented at "Towards Carnegie III" Conference, University of Cape Town, Cape Town, South Africa.

Nkula, K., \& Krauss, K. E. (2014). The integration of ICTs in marginalized schools in South Africa: Considerations for understanding the perceptions of in-service teachers and the role of training. In International Development Informatics Association (IDIA) conference (pp. 3-5). Academic Press.

Oye, N. D., Lahad, N. A., \& Rahim, N. (2014). The history of UTAUT model and its impact on ICT acceptance and usage by academicians. Education and Information Technologies, 19(1), 251-270. doi:10.1007/s10639-012-9189-9

Palak, D., \& Walls, R. T. (2009). Teachers' Beliefs and Technology Practices: A Mixed-Methods Approach. Journal of Research on Technology in Education, 41(4), 417-441. doi:10.1080/15391523.2009.10782537

Pelgrum, W. J. (2001). Obstacles to the integration of ICT in education: Results from a worldwide educational assessment. Computers \& Education, 37(2), 163-178. doi:10.1016/S0360-1315(01)00045-8

Pelgrum, W. J., \& Law, N. (2003). ICT in education around the world: trends, problems and prospects (Fundamentals of educational planning; No. 77). Paris: UNESCO-IIEP.

Prasad, R. (2013). Global ICT Standardisation Forum for India (GISFI) and 5G Standardization. Journal of ICT Standardization, 1(2), 123-136. doi:10.13052/jicts2245-800X.12a1

Pumptow, M., \& Brahm, T. (2020). Students' digital media self-efficacy and its importance for higher education institutions: development and validation of a survey instrument. Tech Know Learn. doi:10.1007/s10758-020-09463-5

Resta, P. (2002). Information and communication technologies in teacher education: A planning guide. United Nations Educational Scientific and Cultural Organization, Division of Higher Education, UNESCO.

Sam, H. K., Othman, A. E., \& Nordin, Z. S. (2005). Computer self-efficacy, computer anxiety, and attitudes toward the Internet: A study among undergraduates in Unimas. Journal of Educational Technology \& Society, 8, 205-219.

Samuel, R. J., \& Bakar, Z. A. (2006). The utilization and integration of ICT tools in promoting English language teaching and learning: Reflections from English option teachers in Kuala Langat District, Malaysia. International Journal of Education and Development using Information and Communication Technology (IJEDICT), 2(2), 4-14.

Scherer, R., \& Siddiq, F. (2015). Revisiting teachers' computer self-efficacy: A differentiated view on gender differences. Computers in Human Behavior, 53, 48-57. doi:10.1016/j.chb.2015.06.038

Shiue, Y. M. (2007). Investigating the sources of teachers' instructional technology use through the decomposed theory of planned behavior. Journal of Educational Computing Research, 36(4), 425-453. doi:10.2190/A40722RR-50X6-2830

Skaalvik, E. M., \& Skaalvik, S. (2007). Dimensions of teacher self-efficacy and relations with strain factors, perceived collective teacher efficacy, and teacher burnout. J. Educ. Psychol., 99(3), 611-625. doi:10.1037/0022-0663.99.3.611

So, H.-J., Choi, H., Lim, W. Y., \& Xiong, Y. (2012). Little experience with ICT: Are they really the Net Generation student-teachers? Computers \& Education, 59(4), 1234-1245. doi:10.1016/j.compedu.2012.05.008

Sun, A., \& Chen, X. (2016). Online Education and Its Effective Practice: A Research Review. Journal of Information Technology Education, 15, 157-190. doi:10.28945/3502

Teo, T. (2009). Examining the relationship between student teachers' self-efficacy beliefs and their intended use of technology for teacher: A structural equation modeling approach. The Turkish Online Journal of Educational Technology, 8(4), 7-16.

Teo, T. (2014). Unpacking teachers' acceptance of technology: Tests of measurement invariance and latent mean differences. Computers \& Education, 75, 127-135. doi:10.1016/j.compedu.2014.01.014 
Teo, T., Chai, C. S., Hung, D., \& Lee, C. B. (2008). Beliefs about teaching and uses of technology among preservice teachers. Asia-Pacific Journal of Teacher Education, 36(2), 165-176. doi:10.1080/13598660801971641

Tezci, E. (2011). Factors that influence preservice teachers' ICT usage in education. European Journal of Teacher Education, 34(4), 483-499. doi:10.1080/02619768.2011.587116

The Complete Works of Swami Vivekananda. (2012). Available at: https://en.wikisource.org/wiki/The_Complete_ Works_of_Swami_Vivekananda/Volume_8/Epistles_-_Fourth_Series/XX_Diwanji_Saheb

The Complete Works of Swami Vivekananda. (2012). Retrieved July, 19, 2020, from https://en.wikisource.org/ wiki/The_Complete_Works_of_Swami_Vivekananda/Volume_8/Epistles_-_Fourth_Series/XX_Diwanji_Saheb

Thirumurthy, V., \& Sundaram, N. (2003). Computers for young children in India. Childhood Education: Annual Theme, 79(5), 307-313. doi:10.1080/00094056.2003.10521217

Tondeur, J., van Braak, J., Sang, G., Voogt, J., Fisser, P., \& Ottenbreit-Leftwich, A. (2012). Preparing pre-service teachers to integrate technology in education: a synthesis of qualitative evidence. Comput. Educ., 59, 134-144. doi: .compedu.2011.10.00910.1016/j

Tschannen-Moran, M., \& Hoy, A. (2001). Teacher efficacy: Capturing an elusive construct. Teaching and Teacher Education, 17(7), 783-805. doi:10.1016/S0742-051X(01)00036-1

UNESCO. (2002). Information and Communication Technology in Education: A Curriculum for Schools and a Program of Teacher Development. UNESCO.

UNESCO. (2018). ICT Competency Framework for Teachers, version 3. https://en.unesco.org/themes/ict-education/ competency-framework-teachers

Unwin, T. (2009). ICT4D. Information and communication technology for development. Cambridge University Press.

Vanderlinde, R., \& van Braak, J. (2010). The e-capacity of primary schools: Development of a conceptual model and scale construction from a school improvement perspective. Computers \& Education, 55(2), 541-553. Advance online publication. doi:10.1016/j.compedu.2010.02.016

Vayre, E., \& Vonthron, A. M. (2016). Psychological engagement of students in distance and online learning: Effects of self-efficacy and psychosocial processes. Journal of Educational Computing Research, 55(2), 197-218. doi: $10.1177 / 0735633116656849$

Venkatesh, V., Morris, M., Davis, G., \& Davis, F. (2003). User acceptance of information Technology: Toward a unified view. Management Information Systems Quarterly, 27(3), 425-478. doi:10.2307/30036540

Wang, L., Ertmer, P. A., \& Newby, T. J. (2004). Increasing Preservice Teachers' Self-Efficacy Beliefs for Technology Integration. Journal of Research on Technology in Education, 36(3), 231-250. doi:10.1080/15391523.2004.107 82414

Ware, H., \& Kitsantas, A. (2007). Teacher and collective efficacy beliefs as predictors of professional commitment. The Journal of Educational Research, 100(5), 303-310. doi:10.3200/JOER.100.5.303-310

Wilson-Strydom, M., \& Thompson, J. (2005). Understanding ICT integration in South African classrooms. Available at: http://wwwshoolnet.org.za/research/Wilson-Strydom_Thomson.doc

World Health Organization. (2020). Coronavirus disease (COVID-19) advice for the public. https://www.who.int/ emergencies/diseases/novel-coronavirus-2019/advice-for-public

Yuen, A., Law, N., \& Wong, K. (2003). ICT implementation and school leadership Case studies of ICT integration in teaching and learning. Journal of Educational Administration, 41(2), 158-170. doi:10.1108/09578230310464666

Yusuf, M.O. (2005). Information and communication education: Analyzing the Nigerian national policy for information technology. International Education Journal, 6(3), 316-321.

Zang, P., \& Aikman, S. (2007). Attitudes in ICT acceptance and use. In J. Jacko (Ed.), Human- computer Interactions: Interaction Design and Usability (pp. 1021-1030). Springer. doi:10.1007/978-3-540-73105-4_112

Zhao, Y., \& Cziko, G. A. (2001). Teacher adoption of technology: A perceptual control theory perspective. Journal of Technology and Teacher Education, 9(1), 5-30. 
Arnab Kundu is a Ph.D. Student, Department of Education, Bankura University, India. He has received a Master of Arts (M.A) in English and in Education, M.Phil. in Education, Post-Graduate Dip. in Educational Management \& Administration (PGDEMA), Post Graduate Dip. in Educational Technology (PGDET). Arnab's research focuses on several issues regarding teachers' work especially to promote literacies in online/digital environments. He is the principal and corresponding author in this research article. He may be contacted at: arnabkundu5@gmail.com

Dr. Tripti Bej has been working as an Assistant Teacher, Department of Mathematics Education, Srima Balika Vidyalaya, Govt. of West Bengal, India for the last thirteen years. She has received a Master of Science (M.Sc.) and Ph. D. in Mathematics from Vidyasagar University, Master of Arts (M.A) in Education from Indira Gandhi National Open University (IGNOU). Her research interest includes Fuzzy, Artificial intelligence, and educational technology. She is the co-author of this paper and may be contacted at: tapubej@gmail.com

Dr. Kedar Nath Dey has been working as an Assistant Professor, Department of Education, SDDK Mahavidyalaya, Bankura University, India. He has received a Master of Arts (M.A) and Ph.D. in Education and now supervising Ph.D. students in their projects. He can be contacted at: kdey975@gmail.com 